Muhammad Fathur Riza, Naelan Ni'mah, Vania Dhea Anggraeni , Siti Nela Lailatul Hidayah, Ro'l Khatul Jannah, Nor Afiyah, Hanik Malichatin

Study Program of Sciences (Tadris IPA), Faculty of Tarbiyah, Institut Agama Islam Negeri Kudus, Indonesia. Email: kknikdr81@gmail.com

\section{Peningkatan Literasi Keluarga dalam Konten Edukatif Pembuatan Brownies Kukus melalui Youtube}

\author{
10.18196/berdikari.v9i1.9804
}

\begin{abstract}
YouTube is an online video site that provides a variety of information in the form of moving and reliable images. Many users access YouTube to find out how to do certain things, such as cooking demos, how to use applications in a computer or smartphone, recycle garbage, practical ways to do things that are initially complicated or ineffective, hone various skills and so on. This is a descriptive qualitative research employing non probability technique, a type of snowball sampling. The ingredients used for making brownies are eggs, baking soda, vanilla, sugar, wheat flour, cocoa powder, oil and water. In the process of steaming the brownies, heat transfer occurs in the form of conduction, convection and radiation and chemical changes also occur in brownies dough into well-cooked brownies cake. This research aims to find out to what extent the family knowledge in using YouTube as a source of information on science in the kitchen. The results obtained by YouTube can easily be accessed by the public. It is also often used by the public to look for recipes because there is a detailed explanation. After watching the video about brownies making; the insights gained about science in the kitchen increased.

Keywords: YouTube, family literacy, brownies, educational content
\end{abstract}

\begin{abstract}
ABSTRAK
Youtube merupakan situs video online yang menyediakan berbagai informasi berupa gambar bergerak dan bisa diandalkan. Banyak pengguna yang mengakses youtube untuk mengetahui cara-cara melakukan beberapa hal tertentu, seperti demo memasak, cara menggunakan aplikasi dalam komputer atau telepon pintar, mendaur ulang sampah, cara praktis melakukan berbagai hal yang awalnya rumit atau tidak efektif, mengasah berbagai skill, dan lain sebagainya. Jenis penelitian ini merupakan penelitian kualitatif deskriptif dan menggunakan teknik non-probability, jenis snowball sampling. Bahan-bahan yang digunakan untuk pembuatan brownis meliputi telur, soda kue, vanili, gula, tepung terigu, coklat bubuk, minyak, dan air. Dalam proses pengukusan brownis, terjadi peristiwa perpindahan kalor berupa konduksi, konveksi, dan radiasi, serta terjadi perubahan kimia dalam adonan brownis menjadi kue brownis yang matang. Penelitian ini bertujuan untuk mengetahui sejauh mana pengetahuan keluarga dalam penggunaan Youtube sebagai sumber informasi pada sains dalam dapur. Hasil yang didapat, youtube dengan mudah dapat diakses oleh masyarakat. Youtube seringkali dimanfaatkan oleh masyarakat untuk mencari resep masakan karena terdapat penjelasan secara detil. Setelah narasumber menonton video mengenai pembuatan brownis, wawasan yang didapat mengenai sains dalam dapur bertambah
\end{abstract}

Kata Kunci:

Youtube, literasi keluarga, brownies, konten edukatif 


\section{PENDAHULUAN}

Pendidikan adalah hal pokok yang akan menopang kemajuan suatu bangsa. Kemajuan suatu bangsa dapat diukur dari kualitas dan sistem pendidikan yang ada. Tanpa pendidikan, suatu negara akan jauh tertinggal dari negara lain. Mutu pendidikan di Indonesia pada dewasa ini sangat memprihatinkan. Hal tersebut ditunjukkan dari indeks pengembangan dan hasil laporan Programme for International Student Assessment (PISA). Menurut data PISA, posisi Indonesia berada pada rangking 6 dari bawah atau di posisi ke-74 dari 79 negara. Melorotnya tingkat literasi pelajar Indonesia menjadi penyebab turunnya kemampuan berpikir kritis mereka. Skor kompetensi membaca pelajar Indonesia paling merosot dari 397 menjadi 371, disusul matematika dari 386 menjadi 379 dan sains dari 403 menjadi 396. Secara nasional yang masuk kategori kurang untuk kemampuan matematika sebanyak 77,13\%, kemampuan membaca 46,83\%, dan kemampuan sains 73,61\% (PISA, 2018).

Hasil survei tersebut mengisyaratkan bahwa minat baca dan literasi bangsa Indonesia merupakan persoalan yang harus ditangani dengan serius. Minat baca dan literasi bangsa kita harus menyamai dan bahkan lebih tinggi daripada bangsa lain yang sudah maju agar bangsa Indonesia juga berperan dalam percaturan di era global. Oleh karena itu, literasi dalam konteks baca tulis menjadi salah satu kebutuhan yang harus dipenuhi dan tidak dapat dipisahkan dari kehidupan sehari-hari. Dalam dunia pendidikan, buku merupakan sumber ilmu, gudangnya ilmu pengetahuan. Akan tetapi, keberadaan buku serasa sudah tidak penting lagi karena perkembangan zaman yang serba modern dengan kemajuan teknologi yang sudah sangat pesat seperti saat ini. Smartphone lebih memiliki daya tarik tersendiri bagi pemiliknya. Melalui berbagai fitur-fitur yang disediakan, smartphone dapat membuat seseorang tertarik untuk menggali fitur-fitur yang telah tersedia. Salah satunya adalah penggunaan youtube. Youtube adalah situs video online yang menyediakan berbagai informasi berupa gambar bergerak dan bisa diandalkan. Youtube disediakan bagi siapapun yang akan mencari informasi video dan menontonnya secara langsung. Sesuai dengan jenis-jenis media sosial, youtube termasuk ke dalam jenis media sharing. Pemanfaatan youtube lebih nyata dan langsung aplikatif terhadap berbagai keperluan dan kebutuhan pengguna. Salah satunya untuk mengakses dan berbagi informasi seputar hal-hal teknis, seperti demo memasak, cara menggunakan aplikasi dalam komputer atau telepon pintar, mendaur ulang sampah, cara praktis melakukan berbagai hal yang awalnya rumit atau tidak efektif, mengasah berbagai skill, dan lain sebagainya.

Selain sebagai konten sharing, youtube juga dimanfaatkan sebagai media literasi 
berbasis digital terutama pada keluarga. Literasi digital merupakan hal penting yang dibutuhkan untuk dapat berpartisipasi di dunia modern sekarang ini. Literasi digital sama pentingnya dengan membaca, menulis, berhitung, dan disiplin ilmu lainnya termasuk sains. Literasi sains dapat diartikan sebagai pengetahuan dan kecakapan ilmiah untuk mampu mengidentifikasi pertanyaan, memperoleh pengetahuan baru, menjelaskan fenomena ilmiah, serta mengambil simpulan berdasarkan fakta, memahami karakteristik sains, kesadaran bagaimana sains dan teknologi membentuk lingkungan alam, intelektual, dan budaya serta kemauan untuk terlibat dan peduli terhadap isu-isu terkait dengan sains (Kementerian Pendidikan dan Kebudayaan, 2017). Dalam keluarga, ibu yang paling berperan dalam mengajarkan kemampuan literasi karena ibu banyak meluangkan waktu di rumah yang berkewajiban untuk mengajarkan literasi (Amariana, 2012). Salah satu contoh yang sering dilakukan yaitu aktivitas yang ada di dapur. Aktivitas di dapur meliputi kegiatan merebus, menggoreng mengukus, dan sebagainya. Selain itu, juga terdapat bahan-bahan dapur yang di dalamnya dapat dijelaskan menurut teori sains yaitu zat aditif seperti gula, telur, soda kue sebagai pengembang, vanili sebagai aroma, tepung, dan sebagainya. Keadaan ini mendorong peneliti untuk kembali mengenalkan, membudidayakan, dan memanfaatkan secara maksimal bahan-bahan karbohidrat lokal untuk memperkuat ketahanan pangan lokal menuju kemandirian pangan kepada keluarga. Bahan pangan lokal sumber karbohidrat seperti tepung yang semula terpinggirkan perlu diperkenalkan kembali dan dikembangkan dalam berbagai diversifikasi produk brownis (Yuliana, 2020).

Bagi sebagian orang, memasak dianggap hanya sekadar membuat makanan menjadi matang saja. Memasak merupakan kegiatan mempersiapkan bahan, peralatan yang digunakan, sampai proses pengolahan sampai bahan makanan siap untuk dimakan (Amaros \& Rohita, 2018). Memasak bukanlah sekadar makanan menjadi matang, tetapi ada juga proses sains yang bekerja seperti perpindahan kalor yang dapat diajarkan kepada keluarga. Sehubung dengan uraian diatas, melalui pengabdian ini diharapkan dapat memberikan kontribusi pada peningkatan literasi keluarga. Tujuan dari kegiatan pengabdian ini adalah untuk meliterasi keluarga tentang sains melalui konten video youtube berjudul Teori Sains dalam Brownies Kukus.

\section{METOdE PELAKSANAAN}

Kegiatan ini merupakan program pengabdian kepada masyarakat yang diselenggarakan LPPM IAIN Kudus. Kegiatan ini dilaksanakan oleh masing-masing pengabdi dengan domisili yang berbeda-beda mencakup empat kota di Jawa Tengah, yaitu Demak, Jepara, 
Kudus, dan Pati dengan waktu pengabdian dua bulan dimulai pada bulan Juli - Agustus 2020. Target kegiatan pengabdian adalah ibu-ibu serta remaja yang memiliki keterampilan memasak. Alat dan bahan yang digunakan dalam pengabdian meliputi alat perekam, kamera, alat tulis, laptop, ponsel dan daftar pertanyaan dalam bentuk google form.

Tabel 1. Lokasi Pengabdian

\begin{tabular}{lll}
\hline Kota & Kecamatan & Desa \\
\hline Demak & Wedung & Babalan \\
Jepara & Nalumsri & Pringtulis \\
& Kalinyamatan & Manyargading \\
Kudus & Gebog & Besito \\
& Dawe & Soco \\
& Jati & Tumpangkrasak \\
& Jati & Loram \\
Pati & Trangkil & Kertomulyo \\
\hline
\end{tabular}

Adapun metode pelaksanaan kegiatan meliputi tahapan sebagai berikut:

1. Pembuatan konten video youtube berjudul "Teori Sains dalam Brownies Kukus" (https://youtu.be/ViqNwxCziKo). Pembuatan video dimulai dari tahap penyusunan script video, perekaman video, proses editing dan proses telaah konten video yang dilakukan ahli.

2. Wawancara awal kepada peserta pengabdian (ibu rumah tangga dan remaja). Proses wawancara awal dilakukan untuk mengeksplorasi pengetahuan peserta terkait keterampilan memasaknya.

3. Mensosialisasikan konten video youtube berjudul "Teori Sains dalam Brownies Kukus" kepada peserta pengabdian.

4. Wawancara kepada peserta setelah mengikuti kegiatan pengabdian.

Data hasil wawancara yang diperoleh dari kegiatan pengabdian dikumpulkan dan dianalisis secara deskriptif terhadap data karakteristik peserta, pengetahuan memasak, dan pengetahuan sains dalam pembuatan brownies. Hasil analisis kemudian disajikan dalam bentuk gambar dan tabel.

\section{HASIL DAN PEMBAHASAN}

Kegiatan pengabdian kepada masyarakat ini memberikan dampak yang positif bagi peserta pengabdian. Peserta dalam kegiatan ini diikuti oleh masyarakat yang bervariasi. Berikut dipaparkan terkait dengan hasil wawancara yang terbagi menjadi 3 bagian, yang pertama pengetahuan memasak, kedua pengetahuan sains dalam pembuatan brownies, ketiga perbandingan pemahaman sebelum dan sesudah kegiatan sosialisasi. 


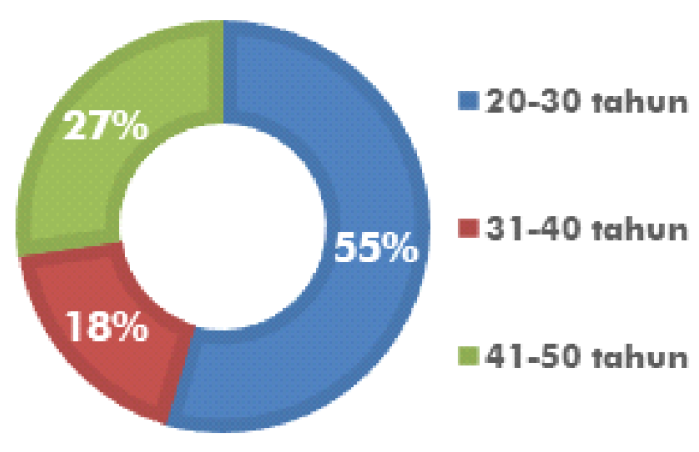

Gambar 1. Variasi Peserta

Pada gambar 1 menginterpretasikan bahwa sebagian besar peserta pengabdian diikuti oleh masyarakat dengan variasi umur 20-30 tahun dengan besar persentase 55\%, 31-40 tahun dengan persentase 18\%, dan 41-50 tahun dengan persentase 27\%. Hal ini berarti bahwa kegiatan ini menjangkau kalangan dari yang muda sampai tua.

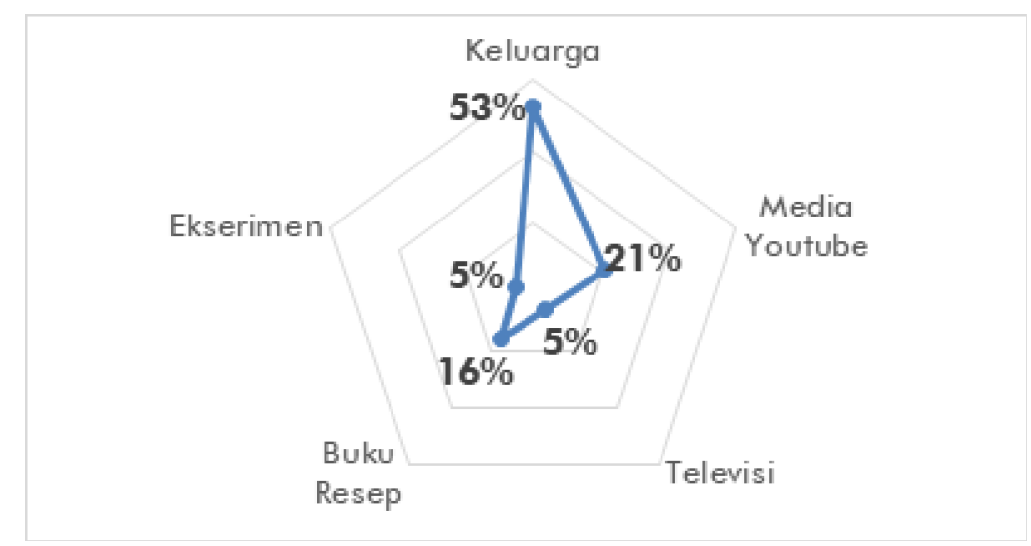

Gambar 2. Sumber Pengetahuan Memasak

Sumber pengetahuan memasak masyarakat dalam pengabdian ini dipaparkan dalam gambar 2 yang berarti pengetahuan masyarakat tertinggi didapat dari keluarga, dalam hal ini adalah ibu dan ayah dengan persentase 53\%. Diikuti media youtube dengan persentase $21 \%$, buku resep $16 \%$, televisi 5\%, dan eksperimen 5\%. Dari hal ini, media youtube memiliki nilai persentase tertinggi kedua setelah keluarga. Ini berarti bahwa masyarakat lebih tertarik dengan sesuatu yang bersifat modern yang dikemas dengan menarik, mudah dipahami dan diakses. 


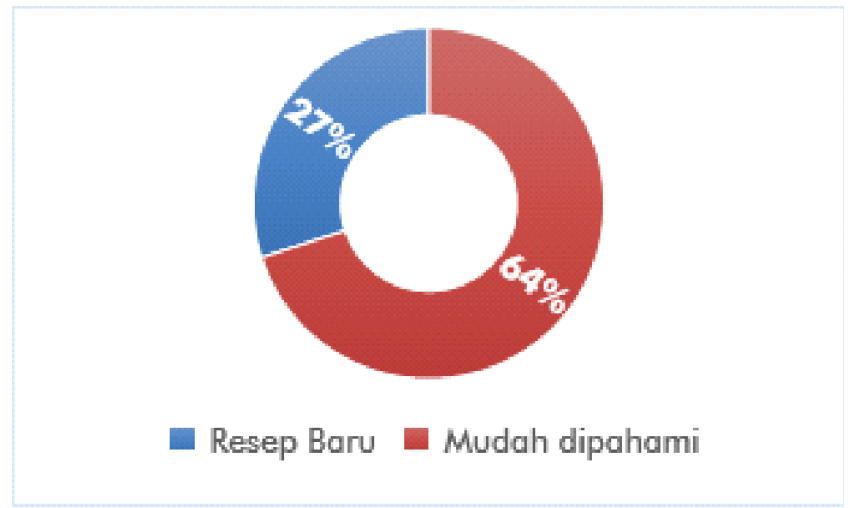

Gambar 3. Manfaat Youtube dalam memasak

Gambar 3 menunjukkan bahwa alasan masyarakat memilih youtube sebagai media dalam meningkatkan pengetahuan memasak adalah karena dua hal. Diantaranya, resep baru yang memungkinkan dapat mengeksplorasi berbagai jenis bahan dan alasan lain yaitu karena kemudahan yang diberikan youtube serta kemudahan dalam memahami konten video. Kedua alasan tersebut dapat berdampak kepada meningkatkannya keterampilan peserta dalam memasak

Bahan yang digunakan dalam pembuatan brownies di antaranya telur, gula, vanili, soda kue, tepung terigu, coklat bubuk, minyak, dan air seperti dalam video vlog yang berjudul Teori Sains dalam Brownis Kukus pada link berikut https://youtu.be/ ViqNwxCziKo.

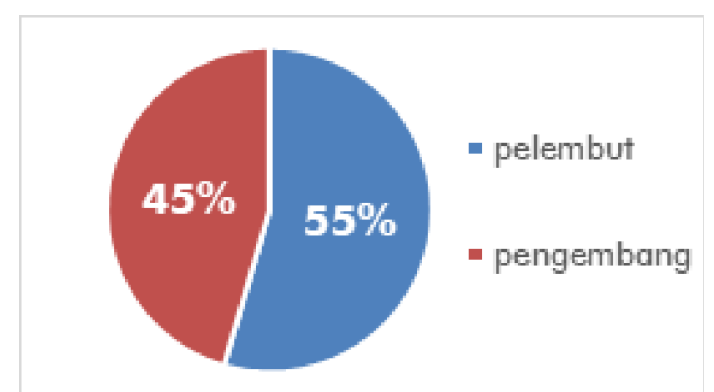

Gambar 4. Persepsi peserta tentang fungsi telur dalam adonan

Pada gambar 4 pengetahuan peserta terkait tentang fungsi telur dalam adonan terbagi menjadi dua, diantaranya pelembut dan pengembang. Telur di dalam adonan berfungsi sebagai pengembang pada produk pangan basah seperti kue kukus. Daya pengembang pada telur disebut daya buih atau daya busa karena mampu membentuk dan menyetabilkan rongga-rongga pada adonan kue kukus (Trianita, 2016). Melalui proses pengocokan telur maka rantai ikatan protein akan terbuka membentuk lapisan 


\section{9}

monomolekuler yang siap menangkap udara. Udara yang terperangkap akan mengisi rongga diantara butiran pati yang telah mengembang. Selama proses pemanasan, udara akan memuai meninggalkan tempatnya bersama dengan pati mengeras, sehingga membentuk pori-pori (rongga antar sel) dengan bentuk besar, merata, dan membuat kue menjadi mengembang. Peserta menyebutkan bahan lain yang memilik fungsi sama dengan telur seperti halnya ovalet, soda kue, dan sprit. Alasan peserta menyebutkan ovalet karena ovalet adalah cake emulsifier yang digunakan sebagai stabilisator adonan dengan menyatukan cairan dengan lemak, sehingga dapat membantu aerasi dan meningkatkan stabilisator adonan. Fungsi cake emulsifier dapat meningkatkan tekstur lebih halus, keempukan cake, memperbaiki atau menambah volume, dan memperpanjang umur simpan cake (Ningrum, 2012). Ovalet sebenarnya bukan bahan pengembang melainkan cake emulsifier atau pelembut dan penstabil adonan cake homogen dan tidak mudah turun saat di kocok serta dicampur dengan bahan-bahan lain. Komposisi kimis ovalet biasanya adalah monogliserida dan disgliserida. Bahan ovalet juga biasanya menggunakan asam lemak dari hewan atau tumbuhan (Fadlilah, 2015). Bahan tambahan sejenis baking soda dapat membantu kue dimana penggunaannya disesuaikan dengan jenis kue yang akan di buat. Pemakaian baking soda memiliki keuntungan, yakni dapat mengurangi penggunaan jumlah telur (Ekayani, 2011). Sprit dalam pembuatan adonan kue merupakan Air Berkarbonasi yang mengandung baking soda. Kandungan Karbondioksida pada air berkarbonasi membantu proses pengembangan adonan dan menghasilkan adonan yang lebih mengembang (Kurniawati, 2019).

Selain telur, ada juga gula. Gula merupakan salah satu bahan dalam pembuatan brownies kukus. Menurut Budi Sutomo (2012: 8), gula pasir terbuat dari cairan sari tebu setelah melalui proses kristalisasi. Ssari tebu ini akan diubah menjadi butiran gula berwarna putih bersih atau putih agak kecoklatan (raw sugar). Fungsi gula pasir dalam pembuatan brownis kukus adalah pemberi rasa manis (Fadlilah, 2015). Peserta menyebutkan bahan lain sebagai pengganti gula diantaranya sari manis. Sakarin mempunyai tingkat kemanisan 200 sampai 700 kali lebih tinggi apabila dibandingkan dengan sukrosa. Sakarin merupakan pemanis alternatif untuk penderita diabetes melitus, karena sakarin tidak diserap kuat sistem pencernaan. Sakarin dapat mendorong sekresi insulin karena rasa manisnya, sehingga gula darah akan turun (Astuti, 2017). 


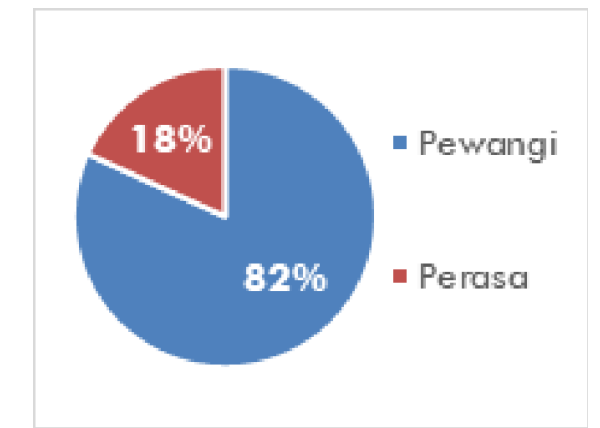

Gambar 5. Persepsi peserta tentang vanilli

Persepsi peserta terkait dengan vanili cukup baik dipaparkan dalam gambar 5. Vanili adalah suatu rempah yang sangat populer dalam pengolahan berbagai macam makanan dan minuman. Rempah ini memiliki aroma yang harum, khas, dan kuat. Bubuknya berwarna putih atau putih kecoklatan dengan tekstur yang agak kasar. Vanili digunakan secara luas pada industri pangan terutama sebagai citarasa (flavor). Citarasa vanili ada yang alami dan ada yang sintetik. Citarasa vanili sintetik hanya mengandung salah satu komponen citarasa vanilla, yaitu vanilin atau etil vanili, sehingga aroma yang dihasilkan tidak sekaya aroma ekstrak vanili alami. Dalam ekstrak vanili alami, terkandung 100 200 komponen senyawa citarasa. Lebih dari seratus senyawa atsiri yang terdeteksi, termasuk karbonil aromatik, alkohol aromatik, asam aromatik, ester aromatik, fenol dan fenol ester, alkohol alifatik, karbonil, asam, ester dan lakton dengan aldehida vanilin adalah yang dominan (Setyaningsih, dkk, 2007). Peserta menyebutkan bahan lain pengganti vanili diantaranya essencial (perasa) pada makanan dimana rasa adalah salah satu kualitas penting dari makanan. Selain perasa, disebutkan terdapat juga daun pandan yang merupakan salah satu jenis herbal yang banyak digunakan untuk penambah aroma dan rasa serta pewarna pada makanan. Daun pandan wangi sering digunakan sebagai bahan penyedap, pewangi, dan pemberi warna hijau pada makanan maupun minuman kandungan kimia yang terdiri dari alkaloid, saponin, flavoida, tannin, polifenol dan aroma harum dari daun pandan wangi berasal dari molekul 2-Acetyl-1-pyrroline (Suryani, $\mathrm{dkk}, 2017$ ).

Selain itu, ada soda kue yang merupakan bahan pengembang dalam pembuatan brownis kukus. Peserta menyebutkan bahan pengganti soda kue yaitu SP yang merupakan nama produk dagang yang memiliki fungsi sebagai penstabil pada emulsi dan berperan sebagai bahan tambahan untuk mempertahankan konsistensi dan bentuk makanan serta sebagai pengembang. Selain itu, peserta juga menyebutkan fermipan yang diketahui bahwa fermipan merupakan ragi instan yang tergolong sebagai organisme ber sel tunggal 
(Kustyawati, 2013). Ragi untuk roti dibuat dari sel khamir Saccharomyces cerevisiae dengan memfermentasi gula, khamir menghasilkan karbondioksida yang digunakan untuk mengembangkan adonan. Akibat fermentasi ini timbul komponen-komponen pembentuk flavor roti, diantaranya asam asetat, aldehid dan ester. Fermipan atau ragi roti ini berfungsi menghasilkan gas karbondioksida untuk pembuat adonan kue dan karbondioksida akan ditangkap oleh gluten sehingga kue dapat mengembang dengan cepat (Kuswara, 2010). Dan peserta menyebutkan baking powder sebagai pengganti soda kue karena baking powder adalah bahan pengembang yang dipakai untuk meningkatkan volume dan memperingan tekstur makanan dan membantu dalam pengempukan kue. Bila baking powder terlalu sedikit maka kue tidak dapat sepenuhnya mengembang, sehingga susunannya menjadi padat dan berat. Baking powder bekerja dengan melepaskan gas karbondioksida ke dalam adonan melalui sebuah reaksi asam basa (Khotijah, 2015).

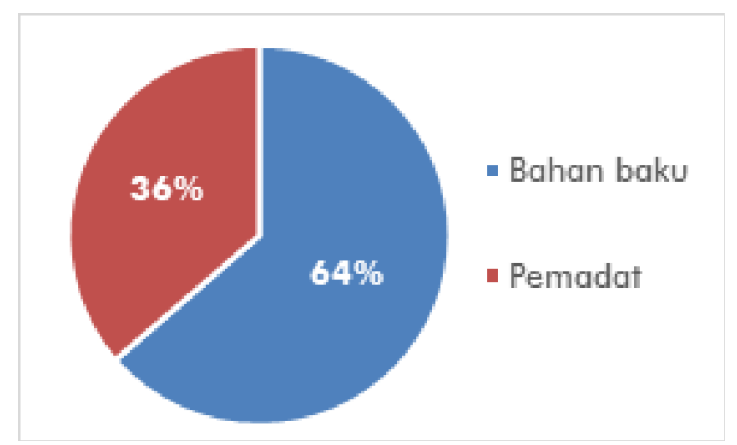

Gambar 6. Persepsi peserta tentang tepung terigu

Terdapat perbedaan persepsi dari peserta terkait dengan terigu yang dimuat dalam gambar 6. Tepung terigu merupakan bahan baku untuk membuat brownis kukus. Tepung terigu merupakan hasil penggilingan biji gandum bagian dalam (endosperma) tanpa melibatkan bagan lembaga dan dedak (lapisan luar) (Astawan, 2009). Tepung terigu terbuat dari biji gandum yang mengandum protein (gluten) rendah sehingga berfungsi sebagai pembentuk struktur dan tekstrur brownies, pengikat bahan-bahan lain dan mendistribusikannya secara merata, serta berperan dalam membentuk cita rasa. Namun, tidak semua orang menggunakan tepung terigu dalam pembuatan brownies. Terkadang orang menggunakan bahan pengganti yang mudah dicari, seperti biskuit oreo. Oreo adalah biskuit komersial paling popular di dunia dan sudah 100 tahun ini sudah dikonsumsi anak-anak dan orang dewasa. Biskuit oreo mengandung dasar tepung terigu, sehingga biskuit ini bisa dijadikan pengganti tepung dalam pembuatan brownies. Selain 
biskuit oreo yang dijadikan bahan pengganti tepung, roti tawar juga digunakan sebagian orang untuk pembuatan brownies. Roti tawar meruapakan salah satu produk turunan dari terigu yang banyak dikonsumsi oleh masyarakat perkotaan sebagai pengganti makanan pokok nasi (Aryani, dkk, 2019). Roti tawar merupakan salah satu pangan olahan dari terigu yang banyak dikonsumsi oleh masyarakat luas (Pusuma, 2018). Protein ini akan berperan untuk mengabsorbsi air membentuk gluten. Gluten merupakan jaringan elastis yang berfungsi menahan gas $\mathrm{CO} 2$ yang dihasilkan pada saat proses fermentasi yang berperan dalam membentuk adonan roti tawar (Rahmah, dkk, 2017). Di dalam roti tawar mengandung terigu, sehingga roti tawar dapat dijadikan bahan pengganti tepung terigu dalam pembuatan brownies yang berfungsi untuk dapat menyerap air dalam jumlah yang besar, dapat mencapai konsistensi adonan yang tepat, memiliki elastisitas yang baik untuk menghasilkan adonan yang halus, tekstur lembut.

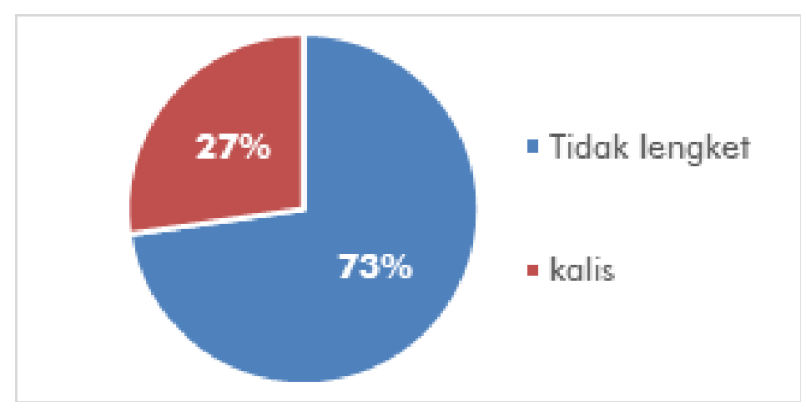

Gambar 7. Persepsi peserta tentang minyak goreng

Persepsi peserta dalam pengabdian ini terkait tentang minyak goreng dipaparkan dalam gambar 7. Minyak goreng digunakan dalam adonan agar adonan tidak lengket dan kalis (tidak encer tidak kental). Minyak goreng adalah minyak nabati yang telah dimurnikan dan dapat digunakan sebagai bahan pangan. Konsumsi minyak goreng biasanya digunakan sebagai media menggoreng bahan pangan, menambah cita rasa ataupun shortening yang membentuk tekstur pada pembuatan roti. Pada umumnya, minyak digunakan untuk menggoreng atau sebagai bahan pengoles. Pada pembuatan brownies kukus, fungsi minyak yaitu memberikan rasa lezat dan memperkaya nilai gizi yang ditambahkan pada adonan setelah telur dan gula dikocok terlebih dahulu. Adapun kandungan gizi pada minyak goreng adalah energi 884 kalori, protein 0 g, lemak 100 g, karbohidrat, kalsium, fosfor, besi, vitamin A, vitamin B, vitamin C, dan air. Selain itu, margarin dan mentega dapat dijadikan sebagai bahan pengganti minyak dalam pembuatan brownies. Adapun fungsi margarin dan mentega dalam pembuatan brownies adalah sebagai pelumas adonan, meningkatkan kelembutan dan keempukan, meningkatkan cita rasa, dan meningkatkan nilai gizi atau nutrisi. Namun, jika lemak 
yang digunakan terlalu banyak akan mengakibatkan brownies lembek dan memiliki daya simpan yang kurang lama (Rahmatiah, 2018).

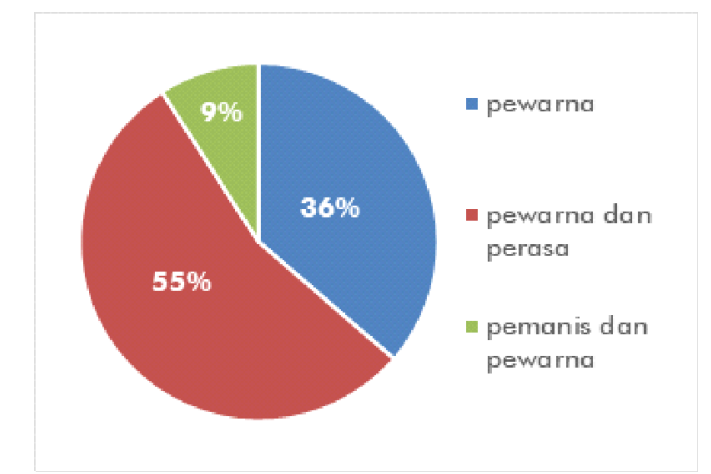

Gambar 8. Persepsi peserta tentang cokelat bubuk

Gambar 8 menunjukkan persepsi peserta terkait peran cokelat bubuk dalam adonan. Cokelat bubuk merupakan bahan yang digunakan sebagai perasa sekaligus pewarna untuk pembuatan brownis. Cokelat adalah makanan yang diolah dari biji kakao. Kandungan dalam cokelat berupa antioksidan dan flavonoid. Cokelat mengandung aroma yang khas. Aroma cokelat yang terbentuk selama penyaringan biji kakao yang merupakan bahan baku dalam pembuatan cocoa powder. Asam amino, peptide, gula pereduksi dan kuinon merupakan pembentuk cita rasa, komponen-komponen termasuk kedalam senyawasenyawa golongan alkohol, eter, furan, tiazol, piron, oksazol, pirazin dan pirol. Hal ini menunjukan bahwa aroma cokelat tidak ditentukan dari satu komponen saja, tetapi terbentuk dari beberapa komponen. Senyawa yang terkandung didalam cokelat terbentuk selama proses fermentasi dan pengeringan. Saat proses penyaringan, senyawa pembentuk cita rasa bereaksi satu sama lain, sehingga menghasilkan komponen-komponen yang mudah menguap dan beraroma khas cokelat. Selain cokelat, bisa diganti bahan lain, yaitu kopi yang juga memiliki aroma khas yang kuat (Rahmatiah, 2018).

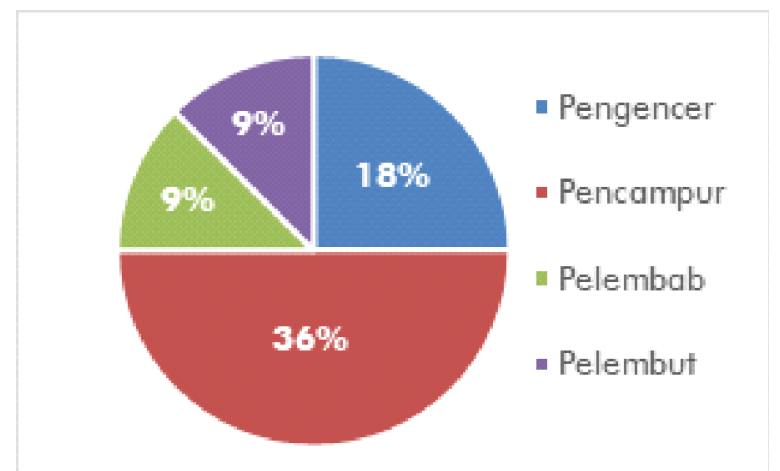

Gambar 9. Persepsi peserta tentang Air 
Gambar 9 menunjukkan persepsi peserta tentang peran air dalam adonan. Air adalah salah satu bahan yang biasanya ditambahkan kedalam adonan pembuatan brownis. Air merupakan bahan yang berperan penting dalam pembuatan roti, antara lain gluten terbentuk dengan adanya air. Air yang masuk ke dalan adonan bahan pangan menyebabkan pengembangan volume pada adonan bahan pangan. Air sangat menentukan konsistensi dan karakteristik reologi adonan yang sangat menentukan sifat adonan selama proses dan akhirnya menentukan mutu produk yang dihasilkan. Air juga berfungsi sebagai pelarut bahan adonan, sehingga bahan tersebut terdispersi secara merata dalam adonan. Kemudian, peserta menyebutkan bahan lain yang memiliki fungsi sama dengan air, yaitu susu cair dan putih telur. Susu cair yang ditambahkan dalam adonan brownis berfungsi membentuk flavor, mengikat air, sebagai bahan pengisi, membentuk struktur yang kuat karena adanya protein, membentuk warna kerena terjadi reaksi pencoklatan dan menambah keempukan karena adanya laktosa. Selain itu, susu cair dapat digunakan sebagai pengganti air karena susu juga dapat memperkuat gluten yang diakibatkan oleh kandungan kalsiumnya. Begitupun juga dengan peran putih telur dalam menggantikan fungsi air, yaitu membantu untuk memperlemas jaringan zat gluten karena adanya lesitin dalam telur yang mengakibatkan kue brownis menjadi lebih empuk dan lemas (Koswara, 2010).

Tabel 2. Pengetahuan Peserta Dalam Proses Memasak Kue Brownies

\begin{tabular}{llll}
\hline Peserta & Proses Perpindahan Kalor & Perubahan Adonan & Waktu Pengukusan \\
\hline 1 & Konduksi dan konveksi & Menjadi padat & 40 menit \\
2 & Adanya api & Mengembang & 30 menit \\
3 & Adanya penghantar panas & Menjadi padat & 20 menit \\
4 & Adanya penghantar panas & Mengembang & 45 menit \\
5 & Adanya penghantar panas & Mengembang & 45 menit \\
6 & Adanya api & Mengembang & 30 menit \\
7 & Adanya api & Mengembang & 20 menit \\
8 & Adanya penghantar panas & Mengembang & 45 menit \\
9 & Adanya penghantar panas & Matang & 20 menit \\
10 & Adanya api & Mengembang & 30 menit \\
11 & Adanya api & Matang & 1 jam \\
\hline
\end{tabular}

Dari tabel 2 terlihat bahwa peserta memiliki pengetahuan dalam proses memasak brownies terjadi peristiwa perpindahan kalor, tetapi banyak yang tidak mengetahui bagaimana alur perpindahan kalor hanya diketahui bahwa terdapat api dan bahan penghantar panas. Adapun satu peserta mengetahui alur perpindahan kalor, tetapi hanya dua peristiwa saja yaitu konduksi dan konvensi, sedangkan peristiwa perpindahan kalor meliputi konduksi, konveksi dan radiasi. Kemudian, peserta mengetahui bahwa dalam 
proses memasak kue brownies terjadi perubahan pada adonan yaitu mengembang dan matang. Begitupula dengan waktu pengukusan kue brownies, peserta memiliki pengetahuan yang berbeda dari waktu 20 menit hingga 1 jam.

Tabel 3. Perbandingan Pemahaman Peserta Terkait Fungsi Bahan dan Proses Memasak

\begin{tabular}{|c|c|c|c|}
\hline \multirow[t]{2}{*}{ No. } & \multirow[t]{2}{*}{ Pertanyaan } & \multicolumn{2}{|l|}{ Jawaban Peserta } \\
\hline & & Sebelum & Sesudah \\
\hline 1. & Telur & $\begin{array}{l}\text { Pengembang, } \\
\text { Melembutkan, } \\
\text { Merekatkan Adonan }\end{array}$ & $\begin{array}{l}\text { Telur sebagai pengemulsi, Telur mengandung protein } \\
\text { dan membuat tekstur adonan menjadi lembut sehingga } \\
\text { terjadi proses koagulasi, Dalam kuning telur berfungsi } \\
\text { sebagai pengemulsi untuk menyatukan minyak dan air. }\end{array}$ \\
\hline 2. & Gula & Pemberi rasa manis & $\begin{array}{l}\text { Terdapat zat aditif dalam bahan-bahan pembuatan } \\
\text { brownis, salah satunya Gula sebagai pemanis Alami }\end{array}$ \\
\hline 3. & Vanili & $\begin{array}{l}\text { Pemberi aroma, } \\
\text { Pengharum, Pewangi }\end{array}$ & $\begin{array}{l}\text { Terdapat zat aditif dalam bahan-bahan pembuatan } \\
\text { brownis, yaitu Vanili yang merupakan zat aditif alami } \\
\text { berperan sebagai pemberi aroma dalam brownis. }\end{array}$ \\
\hline 4. & Soda Kue & $\begin{array}{l}\text { Pengembang, } \\
\text { Pelembut }\end{array}$ & $\begin{array}{l}\text { Terdapat kandungan pada soda kue yang diberikan } \\
\text { kedalam adonan brownies kukus tersebut dan yang } \\
\text { menyebabkan brownies berongga karena adanya } \\
\text { karbondioksida dari reaksi soda kue yang dipanaskan. }\end{array}$ \\
\hline 5. & Tepung Terigu & $\begin{array}{l}\text { Bahan utama brownis, } \\
\text { biar padat }\end{array}$ & Bahan baku pembuatan brownis \\
\hline 6. & Cokelat Bubuk & Pewarna dan perasa & $\begin{array}{l}\text { Terdapat zat aditif dalam bahan-bahan pembuatan } \\
\text { brownis salah satunya yaitu coklat bubuk sebagai } \\
\text { pewarna dan pemberi rasa. }\end{array}$ \\
\hline 7. & Minyak & $\begin{array}{l}\text { Agar adonan tidak } \\
\text { lengket }\end{array}$ & Pelumas adonan dan membentuk tekstur pada kue \\
\hline 8. & Air & $\begin{array}{l}\text { Sebagai pencampur } \\
\text { adonan agar tidak } \\
\text { keras }\end{array}$ & Mengikat adonan kue brownis \\
\hline 9. & $\begin{array}{l}\text { Mengapa panci ketika } \\
\text { diletakkan dikompor } \\
\text { yang menyala menjadi } \\
\text { panas? }\end{array}$ & $\begin{array}{l}\text { Karena api } \\
\text { menyalurkan panas }\end{array}$ & $\begin{array}{l}\text { Terjadi perpindahan kalor yaitu konveksi. Panci } \\
\text { merupakan bahan konduktor berupa alumunium ketika } \\
\text { diletakkan diatas kompor menyala dapat } \\
\text { menghantarkan panas. }\end{array}$ \\
\hline 10. & $\begin{array}{l}\text { Pernahkah anda } \\
\text { merasakan hangat } \\
\text { ketika didekat api atau } \\
\text { kompor atau sumber } \\
\text { panas? menurut anda, } \\
\text { apa penyebabnya }\end{array}$ & $\begin{array}{l}\text { Pernah, karena ada } \\
\text { perantara udara dari } \\
\text { api ke kulit }\end{array}$ & $\begin{array}{l}\text { Terjadi perpindahan kalor yaitu ketika tubuh di dekatkan } \\
\text { kompor terasa hangat karena ada proses radiasi. }\end{array}$ \\
\hline 11. & $\begin{array}{l}\text { Selama waktu } \\
\text { pengukusan, menurut } \\
\text { anda apa yang terjadi } \\
\text { pada adonan brownies? }\end{array}$ & $\begin{array}{l}\text { Adonan mengembang } \\
\text { dan matang }\end{array}$ & $\begin{array}{l}\text { Ketika proses pemanasan terjadi ikatan kimia baru } \\
\mathrm{Na}_{2} \mathrm{CO}_{3} \text { (soda kue) dengan bahan lain dan terbentuk gas } \\
\mathrm{CO}_{2} \text { dalam suhu } 80^{\circ} \mathrm{C} \text { sehingga brownies berongga dan } \\
\text { adonan mengembang hingga matang yang disebut } \\
\text { teori perubahan kimia. }\end{array}$ \\
\hline
\end{tabular}

Perpindahan kalor (heat transfer) adalah ilmu untuk meramalkan atau menggambarkan perpindahan energi yang terjadi karena adanya perbedaan suhu di antara benda atau material. Bila dua sistem yang suhunya berbeda disinggungkan maka akan terjadi 
perpindahan energi. Terdapat tiga macam proses perpindahan energi kalor. Proses tersebut adalah perpindahan energi secara konduksi, konveksi, dan radiasi (Rokhimi \& Pujayanto, 2015). Konduksi adalah proses dimana panas mengalir dari daerah yang bersuhu tinggi kedaerah yang bersuhu lebih rendah di dalam satu medium (padat, cair atau gas) atau antara medium-medium yang berlainan yang bersinggungan secara langsung. Radiasi adalah proses dengan mana panas mengalir dari benda yang bersuhu tinggi ke benda yang bersuhu rendah bila benda-benda itu terpisah di lama ruang, bahkan bila terdapat ruang hampa di antara benda-benda tersebut. Konveksi adalah proses transport energi dengan kerja gabungan dari konduksi panas, penyimpanan dan gerakan mencampur (Supu, dkk, 2016).

Dari Tabel 3 tersebut telihat bahwa peserta mengalami peningkatan pengetahuan dan pemahaman terhadap bahan dan proses pembuatan brownies kukus. Seperti yang terlihat bahwa peserta mengetahui fungsi soda kue bukan hanya sebagai pengembang atau pelembut saja, tetapi sebagai penyebab brownies berongga karena adanya karbondioksida dari reaksi soda kue yang dipanaskan. Kemudian, peserta tidak hanya mengetahui bahwa adonan akan mengembang dan matang pada waktu pengukusan, melainkan ketika proses pemanasan juga terjadi ikatan kimia baru Na2CO3 (soda kue) dengan bahan lain dan terbentuk gas CO2. Selain itu, peserta juga mengetahui peristiwa perpindahan kalor yang terjadi ketika proses pengukusan brownies. Peserta juga menguasai istilah sains dengan baik.

\section{SIMPULAN}

Program meliterasi keluarga dengan menggunakan konten video dari youtube dapat mengubah literasi peserta pengabdian. Dalam pembuatan brownies kukus, terdapat proses sains pada saat proses pengukusan yaitu perpindahan kalor seperti konduksi, konveksi, dan radiasi. Selain itu, bahan-bahan yang digunakan dalam pembuatan brownies kukus dapat dijelaskan menurut teori sains seperti gula sebagai pemanis, telur sebagai pengemulsi, soda kue sebagai pengembang, vanili sebagai pemberi aroma , coklat sebagai pemberi warna, tepung, minyak dan air.

\section{UCAPAN TERIMA KASIH}

1. Ucapan terima kasih terutama kepada Ibu Hanik Malichatin sebagai pembimbing program Pengabdian kepada Masyarakat.

2. Ucapan terima kasih juga diberikan kepada individu yang memberikan sumbangan berarti dalam program tersebut, pengolahan data, dan penulisan artikel tanpa imbalan 
di luar penulis.

3. Ucapan terimakasih tak lupa juga kepada seluruh masyarakat yang telah berpartisipasi dalam proses pelaksanaan pengabdian kepada masyarakat.

\section{DAFTAR PUSTAKA}

Amariana, A. 2012. Keterlibatan Orangtua dalam Perkembangan Literasi Anak Usia Dini. Naskah Publikasi. Fakultas Psikologi Universitas Muhammadiyah Surakarta: 6.

Amaros, Yosi \& Rohita. 2018. Peran Kegiatan Fun Cooking dalam Kemampuan Sosial Emosional dan Bahasa Anak. Jurnal AL-AZHAR INDONESIA SERI HUMANIORA. Vol. 4, No. 4.

Aryani, N. S., Mustofa, A., \& Wulandari Y. W. 2019. Karakteristik Roti Tawar Subtitusi Tepung Kentang (Solanum tuberosum L.) dengan Penambahan Tepung Daun Kelor (Moringa oleivera Lamk.). Jurnal JITIPARI Vol. 4 No.2. 65 73.

Astawan, Made. 2009. Panduan Karbohidrat Terlengkap. Jakarta : Dian Rakyat.

Astuti, E. J. 2017. Penggunaan Sakarin Sebagai Pemanis Sintesis Dalam Makanan Dan Minuman. Prosiding Rapat Kerja Fakultas IImu Kesehatan. Research-report.umm.ac.id.

Ekayani, I. A. P. H. 2011. Efisiensi Penggunaan Telur Dalam Pembuatan Sponge Cake. JPTK Undiksha, Vol. 8 No. 2, 59-74.

Fadlilah, A. N. 2015. Eksperimen Pembuatan Egg Roll Menggunakan Bahan Komposit Tepung Koro Benguk (Mucuna puriens L). Skripsi Fakultas Teknik Unnes.

Kementerian Pendidikan dan Kebudayaan. 2017. Materi Pendukung Literasi Sains. Jakarta: 5

Khotijah, S. F. 2015. Eksperimen Pembuatan Brownies Tepung Terigu Substitusi Tepung Jerami Nangka. Skripsi Fakultas Teknik Unnes.

Koswara, S. 2010. Teknologi Pengolahan Roti. Teknologi Pangan Populer. 2-19.

Kurniawati, N., Pangesthi, L. T. 2019. Pengaruh Subtitusi Tepung Gatot Instan dan Jenis Bahan Pengembang Terhadap Sifat Organoleptik Bolu Kukus. e-journal tataboga. Volume 8 No. 1 edisi yudisium pertama, 40-53.

Kustyawati, M. E., Sari, M., \& Haryati, T. 2013. Efek Fermentasi Dengan Saccharomyces Cerevisiae Terhadap Karakteristik Biokimia Tapioka. Agritech, Vol. 33 No. 3.
Ningrum, M. R. B. 2012. Pengembangan Produk Cake dengan Subtitusi Tepung Kacang Merah. Proyek Akhir, Program Studi Teknik Boga Fakultas Teknik, Universitas Negeri Yogyakarta. PISA. 2018. Results: What Students Know and Can Do. OECD, Volume 1.

Pusuma, D. A., Praptiningsih, Y., \& Choiron, M. 2018. Karakteristik Roti Tawar Kaya Serat yang Disubtitusi Menggunakan Tepung Ampas Kelapa. Jurnal Agroteknologi, Volume 12 No. 01 Rahmah, A., Hamzah, F., \& Rahmayuni. 2017. Penggunaan Tepung Komposit Dari Terigu, Pati Sagu dan Tepung Jagung Dalam Pembuatan Roti Tawar. Jom FAPERTA Volume 4 No.1.

Rahmatiah. 2018. Studi Pembuatan Brownies Kukus Dengan Substitusi Tepung Daun Singkong (Mannihot utilissima). Makassar: Universitas Hasanuddin.

Rokhimi, Intan Nurul \& Pujayanto. 2015. Alat Peraga Pembelajaran Laju Hantaran Kalor Konduksi. Prosiding Seminar Nasional Fisika dan Pendidikan Fisika (SNFPF), Volume 6, No.1.

Setyaningsih, D., Rusli, M. S., \& Muliati, N. 2007. Sifat Fisikokimia dan Aroma Ekstrak Vanili, Jurnal Ilmu Pertanian Indonesia, 173-181.

Supu, Idawati, dkk. 2016. Pengaruh Suhu Terhadap Perpindahan Panas Pada Material Yang Berbeda. Jurnal Dinamika. Volume 07, No. 1.

Suryani, C. L., Tamaroh, S., Ardiyan, A., \& Setyowati, A. 2017. Aktivitas Antioksidan Ekstrak Etanol Daun Pandan (Pandanus amarylifolius) dan Fraksi-Fraksinya, AGRITECH, Vol. 37 No. 3.

Trianita, A. P. 2016. Karakteristik Bolu Kukus yang dibuat dengan Menggunakan Freeze Dried Egg. Skripsi Program Studi S1 Teknologi Pangan Fakultas Peternakan dan Pertanian. Semarang: Universitas Diponegoro.

Yuliana, N., Sartika, D., Nurdin, S. U., Herdiana, N., \& Anungputri, P. S. 2020. Introduksi Produk Olahan Ubi Jalar Pada Anggota Ika Tanjung Sakti, Bandar Lampung. DINAMISIA: Jurnal Pengabdian Kepada Masyarakat. Vol. 4, No. 2, 263-267. 